\title{
Penerapan (Tqm) Pada Lembaga Pendidikan Islam Dalam Perspektif Konsep Edward Deming Dan Joseph Juran
}

\author{
Rizka Arfeinia \\ Institut PTIQ Jakarta \\ zkafheynia@gmail.com
}

\begin{abstract}
Abstrak
Tulisan ini menjelaskan tentang penerapan(TQM) mutu pendidikan yang menjadi prioritas utama di semua lembaga pendidikan. Tulisan memfokuskan pada penerapan prinsip umum Total Quality Management yang meliputi delapan (8) hal yaitu: Mengutamakan Ketercapaian Kepuasan Pelanggan (Customer Focus Organization), Kepemimpinan (Leadership), Keterlibatan Seluruh Partisipan (People Organization), Pendekatan yang menekankan pada perbaikan proses (Process Approach), Pendekatan sistem (System Approach), Perbaikan secara terus menerus (Continual Improvement), Pengambilan keputusan berdasarkan fakta (Factual Approach to Decision Making), dan hubungan dengan supplier yang saling menguntungkan (Mutually Beneficial Relationship). Tulisan menerapkan prinsip umum Total Quality Management yang telah dilaksanakan oleh lembaga pendidikan Islam secara serius, maka diyakini bahwa peningkatan kualitas output yang diharapkan akan dengan mudah dapat dicapai dan akan dapat bersaing dengan lembaga pendidikan lain baik di tingkat nasional bahkan internasional sekalipun. Salah satu upayanya adalah dengan menerapkan berbagai teori dan konsep manajemen mutu agar kualitas pendidikan dapat terjaga dan diakui sebagai lembaga pendidikan yang menjalankan proses dengan baik dan menghasilkan output yang baik. Tulisan ini menggunakan teori Edward Deming dan Joseph Juran yang berkaitan dengan perencanaan mutu, pengendalian dan peningkatan mutu. Tulisan ini akan membahas tentang beberapa penerapan konsep mutu dan relevansinya pada lembaga pendidikan Islam.
\end{abstract}

Kata Kunci: Penerapan, Total Quality Managemen, dan Konsep Teori Edward Daming dan Joseph Juran

This paper explains about the application (TQM) of education quality which is a top priority in all educational institutions. The paper focuses on the application of the general principle of Total Quality Management which includes eight (8) things, namely: Prioritizing Customer Satisfaction Achievement (Customer Focus Organization), Leadership, Involvement of All Participants (People Organization), Approach that emphasizes process improvement (Process Approach) ), System Approach, Continual Improvement, Factual Approach to Decision Making, and Mutual Beneficial Relationship with suppliers. The article applies the general principle of Total Quality Management that has been implemented seriously by Islamic education institutions, so it is believed that the improvement in the quality of output that is expected will be easily achieved and will be able to compete with other educational institutions both at national and even international level. One of the efforts is to apply various theories and concepts of quality management so that the quality of education can be maintained and recognized as an educational institution that runs the process well and produces good output. This paper uses the theories of Edward Deming and Joseph Juran relating to quality planning, quality control and improvement. This paper will discuss some of the applications of the concept of quality and relevance to Islamic educational institutions

Keyword:

\section{PENDAHULUAN}

Tulisan membahas tentang bagaimana penerapan kualitas atau mutu pendidikan merupakan suatu proses yang terintegrasi dengan proses peningkatan kualitas sumber daya manusia itu sendiri. Menyadari pentingnya proses peningkatan kualitas sumber daya manusia, maka pemerintah bersama kalangan swasta sama-sama telah dan terus berupaya 
mewujudkan amanat tersebut melalui berbagai usaha pembangunan pendidikan yang lebih berkualitas atau bermutu. ${ }^{1}$ Problematika yang dihadapi lembaga pendidikan Islam begitu beragam. Mulai dari problem manajemen, problem kepemimpinan, sumber daya manusia, finansial, dan problem kelembagaan. ${ }^{2}$ Peningkatan mutu lembaga pendidikan Islam perlu terus diupayakan dengan mengedepankan teori-teori analisis mutu dan penerapannya. ${ }^{3}$

Secara etimologi dalam kamus Ilmiah popular mutu dapat diartikan sebagai kualitas, derajat, dan tingkat. Dan dalam bahasa Inggris berasal dari kata Quality artinya kualitas. ${ }^{4}$ Dalam rangka umum, mutu mengandung makna derajat (tingkat) keunggulan suatu produk (hasil kerja/upaya) baik berupa barang maupun jasa. Sedangkan Goetsch dan Davis dalam buku Total Quality Management mendefinisikan kualitas merupakan suatu kondisi dinamis yang berhubungan dengan produk, jasa, manusia, proses, dan lingkungan yang memenuhi atau melebihi harapan. ${ }^{5}$

Menurut Crosby mutu adalah sesuai yang disyaratkan atau distandarkan (Conformance to requirement), yaitu sesuai dengan standar mutu yang telah ditentukan, baik inputnya, prosesnya maupun outputnya. Oleh karena itu, mutu pendidikan yang diselenggarakan sekolah dituntut untuk memiliki baku standar mutu pendidikan. Mutu dalam konsep Deming adalah kesesuaian dengan kebutuhan pasar. Dalam konsep Deming, pendidikan yang bermutu adalah pendidikan yang dapat menghasilkan keluaran, baik pelayanan dan lulusan yang sesuai kebutuhan atau harapan pelanggan (pasar)nya. Sedangkan Fiegenbaum mengartikan mutu adalah kepuasan pelanggan sepenuhnya (full customer satisfaction). Dalam pengertian ini, maka yang dikatakan sekolah bermutu adalah sekolah yang dapat memuaskan pelanggannya, baik pelanggan internal maupun eksternal. ${ }^{6}$

Aspek mutu akan memberi manfaat bagi dunia pendidikan setidaknya karena peningkatan mutu merupakan tanggung jawab lembaga pendidikan untuk memberikan layanan pada peserta didik. Peningkatan kualitas atau mutu pendidikan merupakan suatu proses yang terintegrasi dengan proses peningkatan kualitas sumber daya manusia itu sendiri. Konsep Manajemen Mutu sangat berkembang dan banyak diterapkan, khususnya dalam dunia pendidikan. Mc Laughlin menyebutkan bahwa manajemen mutu tidak sekedar suatu pendekatan atau strategi, tetapi lebih merupakan sistem bahkan suatu way of life untuk mencapai tujuan secara efisien agar dapat memenuhi tuntutan pengguna melalui penyempurnaan yang di lakukan secara terus menerus. ${ }^{7}$ Untuk mewujudkan suatu pendidikan yang bermutu dan berdaya saing tinggi, maka lembaga pendidikan (sekolah, pesantren, dan madrasah) harus menerapkan suatu konsep yang berorientasikan pada mutu. Konsep yang dimaksud adalah Manajemen Mutu Terpadu atau sering disebut dengan Total Quality manajemen (TQM). Tulisan ini lebih jauh membahas tentang bagaimana penerapan TQM dalam dunia lembaga pendidikan islam. ${ }^{8}$

\footnotetext{
${ }^{1}$ Umaedi, Manajemen Peningkatan Mutu, Dalam Http:// Ssep.Net /Director. Html. Diakses Pada Tanggal 3 Oktober 2015.

${ }^{2}$ Ahmadi Syukran Nafis, Manajemen Pendidikan Islam, (Yogyakarta, LaksBang PressIndo, 2012), h.11-12.

${ }^{3}$ Saihu Abd Aziz, "Interpretasi Humanistik Kebahasaan: Upaya Kontekstualisasi Kaidah Bahasa Arab," Arabiyatuna 3, no. 2 (2019): 300-314; Saihu, "Rintisan Peradaban Profetik Umat Manusia Melalui Peristiwa Turunnya Adam AS Ke-Dunia," Mumtaz 3, no. 1 (2019): 268-79, https://doi.org/https://doi.org/10.36671/mumtaz.v3i2.44; Saihu Abd Aziz, Athoillah Islamy, "Existence Of Naht Method In The Development Of Contemporary Arabic Language Taqdir: Jurnal Pendidikan Bahasa Arab dan Kebahasaaraban p - ISSN 2527 - 9807 | e - ISSN 2621 - 115719 Existence Of Naht Method In The Development Of Contemporary Arabic Languag," T aqdir: Jurnal Pendidikan Bahasa Arab dan Kebahasaaraban, 2019, 19-28; Saihu Saihu, "Pendidikan Karakter Berbasis Kearifan Lokal (Studi Di Jembrana Bali)," Edukasi Islami: Jurnal Pendidikan Islam 8, no. 01 (2019): 69-90, https://doi.org/10.30868/ei.v8i01.364; Saihu, "Lebaran Sarana Rujuk Nasinal," 2019, http://www.aswajadewata.com/lebaran-sarana-rujuk-nasional/; Saihu, "Teologi Damai Dari Pesantren," 2019, https://www.aswajadewata.com/teologi-damai-dari-pesantren/2019/.

${ }^{4}$ Pius A. Partanto, Kamus Ilmiah Populer (Surabaya: Arkola, 1994), hlm. 505.

${ }^{5}$ Fandy Tjiptono Dan Anstasia Dian, Total Quality Manajemen (Yogyakarta: Andi, 2001), hlm.4.

${ }^{6}$ Crosby, Philip B., Quality Is Free (New York : New American Library, 1979), hlm. 58.

${ }^{7}$ Nana Syaodih, Dkk, Pengendalian Mutu Pendidikan Sekolah Menengah, (Bandung: Refika Aditama, 2008), hlm. 44.

8 Adi Wahidin et al., "Konsep Dasar Perencanaan," 2016; Made Saihu, Merawat Pluralisme Merawat Indonesia: Potret Pendidikan Pluralisme Agama di Jembrana-Bali (Yogyakarta: DEEPPUBLISH, 2019); Saihu, “Urgensi Pendidikan Pluralisme," n.d., https://www.aswajadewata.com/urgensi-pendidikan-pluralisme-
} 
Secara umum, aspek mutu dalam pendidikan mengacu proses belajar dan pembelajaran dan hasil belajar (learning outcomes). Pada titik ini, lembaga pendidikan Islam perlu menunjukkan eksistensinya. Bila tolak ukur kualitas merujuk pada proses pendidikan maka lembaga pendidikan Islam dituntut mampu memperbaiki kualitas pendidikannya mulai dari tingkatan Madrasah Diniyah, Raudhatul Athfal (RA), Madrasah Ibtidaiyah (MI), Madrasah Tsanawiyah (MTs), Madrasah Aliyah (MA),STAIN/IAIN/UIN. Kemudian memperhatikan kebutuhan-kebutuhan stakeholder berkaitan dengan kompetensi lulusan dan kemampuan teknis yang diharapkan di dunia kerja. Konektifitas antara kebutuhan dan keluaran lembaga pendidikan akan memberi dampak pada naiknya daya serap lulusan pendidikan Islam di tengah-tengah masyarakat. Selain itu, jika indikator mutu diarahkan pada hasil belajar, mutu lulusan dan prestasi akademik maka lembaga pendidikan Islam harus menampilkan kualitas dengan bukti-bukti akademik yang dapat diterima dan dipercaya oleh semua pihak sesuai dengan standar yang telah ditetapkan. ${ }^{9}$

Susanto menjelaskan bahwa pendidikan dikatakan bermutu bila digunakan alat ukur yaitu indikator mutu yang dapat dibedakan menjadi lima jenis, yaitu: 1) mutu masukan; 2) mutu proses; 3) mutu output; 4) mutu SDM; 5) mutu fasilitas. ${ }^{10}$ Nana Syaodih dkk. mengungkapkan banyak masalah mutu yang dihadapi dunia pendidikan, seperti mutu lulusan, mutu pengajaran, bimbingan dan latihan guru, serta mutu profesionalisme dan kinerja guru. ${ }^{\text {II }}$ Mutu-mutu tersebut terkait dengan mutu manajerial para pimpinan pendidikan, keterbatasan dana, sarana dan prasarana, fasilitas pendidikan, media, sumber belajar, alat dan bahan latihan, iklim sekolah, lingkungan pendidikan, kelemahan mutu dari komponen-komponen tersebut berujung pada rendahnya mutu lulusan.

Di Indonesia dikenal dengan Manajemen Mutu Terpadu (MMT) yang merupakan suatu pendekatan yang sistematis, praktis, dan strategis bagi penyelenggaraan pendidikan yang mengutamakan kepuasan pelanggan yang bertujuan meningkatkan mutu. Pengertian tersebut tidak menekankan satu komponen dalam sistem pendidikan, tetapi menyangkut seluruh komponen penyelenggaraan pendidikan yaitu input, proses, dan output serta semua perangkat yang mendukungnya. TQM merupakan suatu pendekatan dalam usaha memaksimalkan daya saing melalui perbaikan terus-menerus atas jasa, manusia, produk, dan lingkungan. ${ }^{12}$

Edward Sallis mengemukakan bahwa "Total Quality Management is a philosophy and a methodologhy wich assist institutions to manage change and set their own agendas for dealing with the plethora of new external pressures." (Manajemen mutu terpadu merupakan suatu filsafat dan metodologi yang membantu berbagai institusi, terutama industri dalam mengelola perubahan dan menyusun agenda masing-masing untuk menanggapi tekanan faktor eksternal yang berlebihan). ${ }^{13} \mathrm{TQM}$ adalah suatu system yang efektif untuk mengintegrasikan usahausaha pengembangan, pemeliharaan, dan perbaikan kualitas atau mutu dari berbagai

agama/2019/; Saihu, “Implementasi Manajemen Balanced Score Card di Pondok Pesantren Jam'iyyah Islamiyyah Tangerang Selatan," $\quad$ Mumtaz: $3, \quad$ no. $\quad 1 \quad$ (2019): https://doi.org/https://doi.org/10.36671/mumtaz.v3i2.45; Saihu dan Taufik, "Perlindungan Hukum Bagi Guru," Al Amin: Jurnal Kajian Ilmu dan Budaya Islam 2, no. 2 (2019): 105.

9 Saihu dan Cemal Sahin, "The Harmonious Dialectics Between Hindu-Muslim in Bali (A Study in Jembrana Regency)," Religia Jurnal IImu-IImu Keislaman 80, no. 1 (2020): 56-80; SAIHU, "OPERASIONALISASI TEORI PENDIDIKAN BEHAVIORISTIK DALAM TRADISI NGEJOT DI BALI," Cakrawla: Studi Manajemen Pendidikan Islam Dan Studi Sosial 3, no. 2 (2019): 143-62; Saihu, "PENDIDIKAN KARAKTER BERBASIS KEARIFAN LOKAL (STUDI DI JEMBRANA BALI)," Edukasi Islami: Jurnal Pendidikan Islam 8, no. 1 (2019): 69-90; Saihu, "Urgensi 'Urf dalam Tradisi Male dan Relevansinya dalam Dakwah Islam di Jembrana-Bali," Jurnal Bimas Islam 12, no. 1 (2019): 174-201; Ismail Suardi Wekke et al., "International Relation of The Asia Pasific in The Trump," Journal of Enviromental Treatment Techniques 8, no. 1 (2020): 204-6; Ahmad Zain Sarnoto Saihu, Abd. Aziz, Fatkhul Mubin, "DESIGN OF ISLAMIC EDUCATION BASED ON LOCAL WISDOM (An analysis of Social Learning Theories in Forming Character through NgejotTradition in Bali)," International Journal of Advanced Science and Technology 29, no. 6 (2020): 1278-93.

${ }^{10}$ Pendi Susanto, op.cit.h. 158 .

11 Nana Syaodih Sukmadinata, dkk., Pengendalian Mutu Pendidikan Sekolah Menengah: Konsep, Prinsip dan Instrumen, (Bandung: Kusuma Karya, 2002), h. 8. 2006), hlm. 458.

Husaini Usman, Manajemen Teori, Praktik, Dan Riset Pendidikan, (Jakarta: Bumi Aksara,

${ }_{13}$ Edward Sallis, Total Quality Management In Education, Terj. Ahmad Ali Riyadi, Cet. Ke4(Yogyakarta: Ircisod, 2011), hlm. 33. Lihat Juga Dalam Agus Fahmi, Dkk, Konsep Pendidikan.... hlm. 68. 
kelompok atau organisasi, sehingga meningkatkan produktivitas dan pelayanan ketingkat yang paling ekonomis yang menimbulkan kepuasan semua langganan. ${ }^{14}$

Dapat disimpulkan bahwa Total Quality Management (Manajemen Mutu Terpadu) merupakan suatu pendekatan manajemen yang berorientasi pada peningkatan mutu produk yang dihasilkan oleh sebuah lembaga, organisasi untuk kepuasan pelanggan. Untuk itu harus ada perbaikan terus menerus yang dilakukan oleh lembaga. TQM memfokuskan proses atau sistem pencapaian tujuan organisasi. Dengan dimulai dari proses perbaikan mutu, maka TQM diharapkan dapat mengurangi peluang membuat kesalahan dalam menghasilkan produk, karena produk yang baik adalah harapan para pelanggan. Jadi, rancangan produk diproses sesuai dengan prosedur dan teknik untuk mencapai harapan pelanggan. Menurut hansler dan brunell dalam Sceuing dan christopher yang dikutip oleh husaini usman ada lima prinsip utama dalam TQM yaitu sebagai berikut: a) Fokus terhadap pelanggan; dalam TQM konsep mengenai kualitas dan pelanggan diperluas. Kualitas tidak hanya bermakna kesesuaian dengan spesifikasi-spesifikasi tertentu, tetapi kualitas tersebut di tentukan oleh pelanggan. Pendidikan adalah pelayanan jasa. Sekolah harus memberikan pelayanan jasa sebaik-baiknya kepada pelanggannya. ${ }^{15}$ Pelanggan sekolah meliputi pelanggan internal dan pelanggan eksternal. Pelanggan eksternal sekolah adalah orang tua siswa, pemerintah, dan masyarakat termasuk komite sekolah. Pelanggan internal sekolah adalah siswa, guru, dan staf tata usaha. Dalam arti lain sekolah mempunyai pelanggan primer, sekunder dan tersier. Pelanggan primer sekolah adalah siswa, pelanggan sekunder sekolah adalah orang tua siswa, pelanggan tersier adalah pemerintah dan masyarakat. ${ }^{16}$

Seorang pemimpin mampu menentukan kesatuan arah dan tujuan organisasi. Pemimpin harus menciptakan dan menjaga atau memlihara lingkungan eksternal dimana orang-orang dapat terlibat secara penuh dalam pencapaian tujuan-tujuan organisasi. Dalam implementasi TQM, seorang kepala sekolah harus berperan sebagai penasehat sekaligus motor penggerak dalam upaya perbaikan. Oleh karena itu, kepala sekolah harus memahami tujuan, prinsip, dan elemen pendukung TQM serta mampu megelolanya secara terus menerus demi peningkatan kualitas lembaga pendidikan. ${ }^{15}$ Kebutuhan pelanggan di usahakan untuk dipuaskan dalam segala aspek, termasuk didalamnya harga, keamanan, dan ketepatan waktu. Oleh karena itu segala aktivitas harus dikoordinasikan untuk memuaskan para pelanggan. Kualitas yang dihasilkan sama dengan nilai yang di berikan dalam rangka meningkatkan kualitas hidup para pelanggan. Semakin tinggi nilai yang di berikan, maka semakin besar pula kepuasan pelanggan. Intinya adalah semua pelanggan TQM harus dipuaskan. ${ }^{17}$

Ada beberapa penerapan khusus bagi kepemimpinan, yakni: 1) pertimbangkan kebutuhan semua pihak yang berkepentingan termasuk pelanggan; 2) tetapkan dan jelaskan visi organisasi kedepan agar setiap orang mengerti tujuan; 3) tentukan sasaran dan target yang menantang dan sosialisasikan; 4) ciptakan dan sokong nilai-nilai kebersamaan, kejujuran dan model tugas yang etis pada semua level organisasi; 4) lengkapi semua orang dengan sumber daya yang diperlukan (misalnya ; pelatihan sesuai keperluan bidang tugas), dan beri kebebasan bertindak dengan penuh tanggung jawab; 5)beri semangat kebesaran hati dan pengakuan terhadap kontribusi setiap orang. ${ }^{18}$

219

${ }^{14}$ Malayu S.P. Hasibuan, Manajemen Sumber Daya Manusia (Jakarta: Bumi Aksara, 20oo), hlm.

${ }^{15}$ Husaini Usman, Manajemen ...., hlm. 464.

${ }^{16}$ S. Soimatul Ula, Buku Pintar...., hlm. 46.

${ }^{17}$ Husaini Usman, Manajemen ...., hlm. 464.

18 Saihu, "Pendidikan Sosial Yang Terkandung dalam Surat AT-Taubah Ayat 71-72," Edukasi Islami: Jurnal Pendidikan Islam 09, no. 01 (2020): 146, https://doi.org/10.30868/ei.v9i01.703; Saihu, “Konsep Pembaharuan Pendidikan Islam Menurut Fazlurrahman," Andragogi: Jurnal Pendidikan Islam 2, no. 1 (2020): 85, https://doi.org/org/10.36671/andragogi.v1i3.66; Agus Mailana Saihu, "Teori pendidikan behavioristik pembentukan karakter masyarakat muslim dalam tradisi Ngejot di Bali," Ta'dibuna 8, no. 2 (2019): 168; SAIHU, "KONSEP MANUSIA DAN IMPLEMENTASINYA DALAM PERUMUSAN TUJUAN PENDIDIKAN ISLAM MENURUT MURTADHA MUTHAHHARI," Andragogi 1, no. 2 (2019): 197-217; Saihu, "Pendidikan Pluralisme Agama: Kajian Tentang Integrasi Agama dan Budaya dalam Menyelesaikan Konflik Sosial Kontemporer," Indo-Islamika 9, no. 1 (2019): 67-90; Abd Aziz, Athoillah Islamy, dan Saihu, "Existence of Naht Method in the Development of Contemporary Arabic Language," Taqdir: Jurnal Pendidikan Bahasa Arab dan Kebahasaaraban 5, no. 2 (2019), https://doi.org/https://doi.org/https://doi.org/10.19109/taqdir.v5i2.4926; Saihu, “Modernisasi Pendidikan Islam," Al Amin: Jurnal Kajian IImu dan Budaya Islam 1, no. 1 (2018): 1-33. 
Menurut Goetch dan Davis yang dikutip oleh Husaini Usman Komponen TQM memiliki 10 unsur utama yang masing-masing akan dijelaskan sebagai berikut: ${ }^{19}$ a) fokus Pada Pelanggan; Dalam TQM, baik pelanggan internal maupun pelanggan eksternal merupakan driver. Pelanggan eksternal menentukan mutu lulusan sedangkan pelanggan internal berperan besar dalam menentukan kualitas manusia, proses, dan lingkungan yang berhubungan dengan lulusan; b) obsesi terhadap Kualitas; Dalam organisasi yang menerapkan TQM, pelanggan menentukan mutu. Dengan mutu tersebut, organisasi harus terobsesi untuk memenuhi yang diinginkan pelanggan. Hal ini berarti bahwa semua karyawan berusaha melaksanakan setiap aspek pekerjaannya. Apabila suatu organisasi terobsesi dengan kualitas, maka berlaku prinsip'good enough is never good enough'; c) pendekatan ilmiah; Pendekatan ini sangat di perlukan terutama untuk mendesain pekerjaan dalam proses pengambilan keputusan dan pemecahan masalah yang berkaitan dengan pekerjaan yang didesain tesebut. Dengan demikian data di perlukan dan dipergunakan dalam menyusun patok duga (benchmark), memantau prestasi, dan melaksanakan perbaikan; d) komitmen Jangka Panjang; TQM merupakan suatu paradigma baru. Untuk itu dibutuhkan budaya sekolah yang baru pula. Oleh karena itu komitmen jangka panjang sangat penting guna mengadakan perubahan agar penerapan TQM dapat berjalan dengan sukses; e) kerjaSama Tim (Teamwork); Sementara itu dalam organisasi yang menerapkan TQM, kerjasama tim, kemitraan dan hubungan dijalin dan dibina, baik antar warga sekolah maupun dengan luar sekolah; f) perbaikan Sistem Secara Berkesinambungan; Setiap produk atau jasa dihasilkan dengan memanfaatkan proses-proses tertentu didalam suatu sistem atau lingkungan. Oleh karena itu system yang ada perlu diperbaiki secara terus menerus agar kualitas yang dihasilkan dapat meningkat; g) pendidikan dan Pelatihan; Pendidikan dan pelatihan merupakan faktor yang fundamental. Organisasi yang menutup mata atas pendidikan dan pelatihan akan menyebabkan organisasi tersebut tidak berkembang dan sulit bersaing dengan organisasi lainnya; h) kebebasan yang Terkendali; Keterlibatan dan pemberdayaan guru dan staf tata usaha dalam pengambilan keputusan dan pemecahan masalah sangant penting karena dapat meningkatkan rasa saling memiliki dan tanggungjawab terhadap keputusan yang dibuat serta dapat memeperkaya wawasan dan pandangan dala suatu keputusan meskipun demikian kebebasan yang timbul karena keterlibatan dan pemberdayaan tersebut merupakan hasil pengendalian yang terrencana. Pengendalian dilakukan terhadap metode pelaksaan setiap proses, dalam hal ini karyawan yang melakukan standarisasi proses dan mereka pula yang berusaha mencari cara untuk meyakinkan setiap orang agar bersedia mengikuti prosedur tersebut. I) kesatuan Tujuan; Supaya TQM dapat diterapkan dengan baik maka sekolah harus memiliki kesatuan tujuan. Dengan demikian setiap usaha dapat diarahkan pada tujuan yang sama. Akan tetapi kesatuan tujuan ini tidak berarti bahwa harus selalu ada persetujuan/kesepakatan antara pihak sekolah dan duru serta staf tata usaha mengenai upah dan kondisi kerja; j) adanya Keterlibatan dan Pemberdayaan Karyawan; Keterlibatan dan pemberdayaan karyawan merupakan hal yang penting dalam penerapan TQM. Usaha untuk melibatkan karyawan membawa 2 manfaat utama. Pertama, hal ini akan meningkatkan kemungkinan dihasilkannya keputusan yang baik, rencana yang lebih baik, atau perbaikan yang lebih efektif karena juga mencakup pandangan dan pemikiran dari pihak-pihak yang langsung berhubungan dengan situasi kerja. Kedua, keterlibatan guru juga meningkatkan "rasa memiliki" dan tanggung jawab atas keputusan dengan melibatkan orang-orang yang harus melaksanakannya.

\section{HASIL DAN PEMBAHASAN}

\section{Konsep Mutu Edward Deming dan Joseph Juran}

Edward Deming (1986) berpendapat bahwa meskipun kualitas mencakup kesesuaian atribut produk dengan tuntutan konsumen, namun kualitas harus lebih dari itu. Demikian pula pendapat Deming sebagaimana dikutip Kambey yang menyatakan bahwa permasalahan utama kualitas/mutu secara mendasar berkaitan dengan manajemen.

Oleh karena itu, Deming mengemukakan 14 poin penting yang dapat menuntun manager mencapai perbaikan dalam kualitas yaitu: 1) Menciptakan kepastian tujuan perbaikan produk dan jasa; 2) Mengadopsi filosofi baru dimana cacat tidak bisa diterima; 3 ) Berhenti tergantung pada inspeksi massal; 4) menghentikan praktek penghargaan atas dasar harga saja;

${ }^{19}$ Ibid., hlm. 463. 
5) Secara tetap dan berkelanjutan memperbaiki sistem produksi dan jasa; 6) Mengadakan pelatihan kerja modern; 7) Membentuk kepemimpinan; 8) Menghilangkan ketakutan; 9) Singkirkan penghalang antar depertemen; 10) Hilangkan/kurangi tujuan-tujuan, target jumlah pada pekerja; 11) Hilangkan manajemen berdasarkan sasaran; 12) Hilangkan rintangan yang merendahkan pekerja berdasarkan penilaian; 13) Melembagakan program pendidikan dan pelatihan; 14) Menciptakan struktur dalam manajemen puncak yang dapat melaksanakan transformasi. ${ }^{20}$ Secara umum, Deming mengedepankan langkah antisipasi atau pencegahan dalam menjamin perbaikan kualitas. Melihat uraian 14 poin tersebut, Deming ingin menyampaikan bahwa peningkatan kualitas berawal dari tujuan, melakukan perbaikan terus menerus dengan memfokuskan pada pendidikan dan latihan pada staf agar pelaksanaan setiap kegiatan dapat berjalan baik dengan jaminan kualitas yang terjaga. Semua itu terbangun dan berjalan maksimal jika faktor kepemimpinan secara kelembagaan dan struktural mampu menggerakan staf dengan baik untuk mencapai tujuan.

Selain itu, Deming mempopulerkan siklus manajemen yang menjadi acuan dalam kegiatan penjaminan mutu yaitu Plan, Do, Check, Action (PDCA). Tahapan ini diawali dari Plan atau membuat perencanaan, Do atau kegiatan melaksanakan rencana, Check atau kegiatan evaluasi semua aktivitas yang telah dilaksanakan, serta Action atau tindak lanjut. ${ }^{21}$ Perencanaan/ Plan, merupakan kegiatan meliputi penetapan standar, terutama terkait dengan standar kinerja pendidik/guru, pengalam belajar, standar hasil belajar peserta didik.

Selanjutnya Do, Pelaksanaan proses pendidikan (proses pembelajaran) yang sesuai dengan standar kinerja agar peserta didik dapat mencapai pengalaman belajar dan hasil yang diharapkan. Check atau Evaluasi merupakan upaya membandingkan pelaksanaan proses dengan standar yang ditetapkan, apakah sudah sesuai atau terdapat kekurangan yang akan ditindak lanjuti dalam action yakni perbaikan lanjutan berdasarkan hasil evaluasi.

Sejalan dengan Deming, Joseph Juran memiliki keyakinan bahwa masalah kualitas dapat ditelusuri sampai pada keputusan-keputusan manajemen. Menurut Juran, $85 \%$ dari permasalahan-permasalahan kualitas/mutu organisasi disebabkan karena proses-proses yang dirancang dengan buruk. Oleh karena itu, perlu adanya perencanaan kualitas yang baik seperti disebut Juran sebagai Strategic Quality Management yaitu proses perbaikan kualitas. ${ }^{22}$ Konsep Juran yang terkenal yaitu Trilogi Juran (1989) menyebutkan bahwa manajemen mutu terdiri dari tiga bagian pokok, yaitu: (a) perencanaan mutu, (b) pengendalian mutu, dan (c) peningkatan mutu.

Juran menggambarkan sebuah sistem manajemen mutu yang berkaitan antara perencanaan, pengendalian dan perbaikan atau peningkatan kualitas. Isi pokok perencanaan mutu ialah mengidentifikasi kebutuhan-kebutuhan pelanggan, menerjemahkan kebutuhan itu ke dalam program kegiatan, dan menyusun langkah-langkah dalam proses pelaksanaan program untuk menghasilkan produk yang bermutu. Menurut Juran (1987) Kualitas adalah kesesuaian untuk penggunaan (fitness for use), ini berarti bahwa suatu produk atau jasa hendaklah sesuai dengan apa yang diperlukan atau diharapkan oleh pengguna. Perencanaan mutu menjadi proses awal dalam suatu siklus manajemen kualitas. Trilogi Juran (1986) menunjukkan tiga proses penting yang saling terkait, yaitu perencanaan kualitas quality planning, quality control, dan quality improvement. ${ }^{23}$ Tahap perencanaan kualitas menyangkut penentuan kebutuhan customer dan pengembangan produk beserta proses yang diperlukan untuk memenuhi kebutuhan konsumen. Pengendalian kualitas menjadi proses penting untuk memastikan bahwa realisasi operasional produksi sesuai dengan perencanaan yang telah ditetapkan. Peningkatan kualitas menjadi suatu proses bagi perusahaan untuk memperoleh konsumen dan menjadikannya sebagai pelanggan tetap. Usaha untuk peningkatan kualitas tidak terlepas dari perencanaan kualitas, karena kualitas yang baik disebabkan oleh perencanaan yang tepat.

Proses perencanaan kualitas merupakan penetapan design, layanan, atau proses yang dibutuhkan custormer, usaha, dan kebutuhan operasional untuk menghasilkan produk sebelum diproduksi (Juran, 1993). Pendekatan Juran terhadap perencanaan kualitas (quality

${ }^{20}$ Daniel C. Kambey, Manajemen Kualitas Total dalam Pendidikan (Terjemahan Buku Total Quality Management, Edward \& Sallis), (Pascasarjana Universitas Negeri Manado, 2004), h. 36-38.

${ }^{21}$ Ridwan Abdullah Sani, dkk, op.cit. h. 11

${ }^{22}$ Ibid., h. 41.

${ }^{23}$ Joseph Juran., “The Juran Trilogy”, Quality Progress, Vol. 19, No. 8, 1986. h. 19. 
planning) melibatkan beberapa aktivitas yakni: 1) Identifikasi pelanggan; 2) Menentukan kebutuhan pelanggan; 3) Menciptakan keistimewaan produk yang dapat memenuhi kebutuhan pelanggan; 4) Menciptakan proses yang mampu menghasilkan keistimewaan produk di bawah kondisi operasi; 5) Mentransfer/mengalihkan proses ke operasi. ${ }^{24}$

Dalam dunia pendidikan perencanaan, pengendalian dan perbaikan atau peningkatan kualitas sangat penting untuk menjamin mutu pendidikan sesuai dengan standar yang telah ditetapkan Badan Standar Nasional Pendidikan (BSNP). Pelaksanaan kegiatan penjaminan mutu baik internal maupun eksternal sangat bermanfaat bagi dunia pendidikan secara umum. Mengutip pendapat Philip Crosby yang menginginkan adanya Tim Perbaikan Kualitas, maka keberadaan tim penjaminan mutu sangat dibutuhkan.

\section{Upaya Peningkatan Mutu Pendidikan Islam}

Bagi setiap lembaga pendidikan mutu adalah suatu isu sentral yang perlu diperhatikan. Menurut Ismail, penerapan manajemen mutu dalam dunia pendidikan merupakan memerlukan adanya pengelolaan yang baik dan profesional, manajemen organisasi yang baik dan penyediaan personil yang memadai dalam menjalankan proses yang baik sehingga menghasilkan output yang bermutu dan berkualitas tinggi. ${ }^{25}$ Dalam hal mutu dan kualitas pendidikan terdapat suatu standar yang ditentukan dalam standar nasional pendidikan. Standar nasional yang ditetapkan merupakan standar yang sudah dikaji dan dapat dicapai oleh setiap lembaga pendidikan di Indonesia. Konsep tentang standarisasi pendidikan nasional berimplikasi pada peningkatan mutu pendidikan, sehingga diharapkan dengan adanya standar nasional dapat memotivasi sekolah untuk memberikan layanan yang terbaik bagi peserta didik di lingkungan pendidikannya. Oleh karena itu, penjaminan mutu harus terus dilakukan untuk mencapai standar nasional pendidikan.

Inti penjaminan mutu adalah rencana dan tindakan sistematis dalam menyediakan kepercayaan terhadap mutu. Dalam kegiatan ini, tujuan utamanya adalah penyempurnaan dan upaya untuk mencapai Standar Nasional Pendidikan dan melakukan peningkatan. Berdasarkan model penjaminan mutu, pada prosesnya penjaminan mutu mengandung 4 ciri fungsional yaitu, penetapan standar, pemenuhan standar, evaluasi, dan peningkatan mutu. ${ }^{26}$

Dalam kaitan ini, lembaga pendidikan Islam perlu melakukan evaluasi diri untuk mengetahui sudah sampai dimanakah proses penjaminan mutu dilakukan dalam tiap satuan pendidikan Islam. Berapa jumlah lembaga pendidikan Islam yang sudah terakreditasi dan memenuhi standar dan berapa banyak lembaga pendidikan Islam yang sudah menapaki tahapan peningkatan mutu pendidikan. Evaluasi ini penting untuk mengetahui posisi lembaga pendidikan Islam dalam standar nasional pendidikan yang telah ditetapkan.

Permasalahan yang sering tampak dalam pengelolaan lembaga pendidikan Islam adalah aspek manajemen, kepemimpinan, sumber daya manusia, finansial, dan aspek kelembagaan. Oleh karena itu, ada beberapa upaya yang dapat dilakukan dalam peningkatan kualitas pendidikan Islam. Secara manajemen, masih banyak lembaga pendidikan Islam yang belum mengadopsi manajemen modern dalam pengelolaan pendidikan. Meski demikian sudah mulai tampak pesantren dan madrasah yang mulai menggunakan kata modern dan penggunaan kata asing pada nama lembaga dan program kegiatannya. Padahal, intinya terletak pada proses manajerial bukan pada nama dan programnya. Dalam hal kepemimpinan dan sumber daya manusia juga menjadi problem tersendiri yakni masih banyak yang belum memenuhi kualifikasi akademik minimal yang dipersyaratkan. Hal ini menuntut para pendidik dan tenaga kependidikan mengikuti pendidikan, akan tetapi realitasnya masih jauh dari harapan peningkatan kualitas karena tujuannya baru sekadar memenuhi tuntutan Undang-undang. Demikian pula dengan aspek finansial yang masih membutuhkan dukungan dari berbagai pihak serta pengembangan lembaga pendidikan Islam agar lebih profesional.

Plan, Do, Check, Action (PDCA) juga perlu diterjemahkan dalam pengelolaan lembaga pendidikan Islam. Perencanaan, pelaksanaan, evaluasi dan tindak lanjut menjadi alat kontrol

24 Gusti Lestari, Penerapan Sistem Manajemen Mutu ISO 9001:2008 di Perusahaan Konstruksi, Ganeç Swara Vol. 9 no.1. 2015. h.123.

${ }_{25}$ Feiby Ismail, "Implementasi Total Quality Management (TQM) di Lembaga Pendidikan”, Jurnal Pendidikan Islam IQRA, Vol.2. Nomor 2. 2016, h. 26.

${ }^{26}$ Dede Rosyada, Madrasah dan Profesionalisme Guru, (Depok, Kencana, 2017), h. 42-43. 
bagi setiap elemen dalam menjaga mutu pendidikan Islam. Perencanaan, pelaksanaan, evaluasi pendidikan Islam diarahkan pada penyiapan lulusan yang berkualitas dengan landasan nilai-nilai Islam. Merujuk pada Trilogi Juran, mutu lembaga pendidikan Islam dapat ditingkatkan dengan melakukan pembenahan pada aspek perencanaan mutu/kualitas, pengendalian mutu/kualitas, dan peningkatan mutu/kualitas. Isi pokok perencanaan mutu ialah mengidentifikasi kebutuhan-kebutuhan masyarakat terhadap lembaga pendidikan Islam seperti pesantren dan madrasah. Apa yang diharapkan dari lulusannya serta kebutuhan apa yang mendesak dihadapi oleh umat Islam. Selanjutnya, lembaga pendidikan Islam harus menerjemahkan kebutuhan itu ke dalam program kegiatan, dan menyusun langkah-langkah dalam proses pelaksanaan program untuk menghasilkan peserta didik yang bermutu.

Tahapan pengendalian mutu dalam pendidikan Islam dapat dimaknai sebagai proses untuk memastikan bahwa implementasi program telah terlaksana dengan baik. Aspek operasional berjalan sesuai dengan perencanaan yang telah ditetapkan. Peserta didik mampu menunjukkan harapan-harapan yang ditetapkan dalam standar kompetensi lulusan. Kemudian sebagai tindak lanjut, perlu adanya evaluasi untuk peningkatan kualitas menjadi suatu proses bagi lembaga menjaga kualitas dan meningkatkan dengan melakukan terobosan baru yang sesuai dengan tuntutan zaman.

Kurikulum pendidikan Islam harus mampu menjawab tantangan zaman, sehingga perlu dilakukan pengembangan kurikulum pendidikan Islam secara terus menerus. Pembenahan aspek materi pelajaran yang up to date, revisi model dan metode pembelajaran yang dilakukan secara bersamaan dengan peningkatan kualitas guru di madrasah dan pesantren. Pembelajaran lebih mengarah pada pemecahan masalah aktual di masyarakat didasarkan pada landasan Al-Qur'an dan Hadis. Sehingga pendidikan Islam menjadi jawaban atas permasalahan yang dihadapi. Hal ini akan meningkatkan daya tarik lembaga pendidikan Islam. Pemenuhan sarana dan prasarana juga tidak kalah pentingnya. Pengembangan materi agama dalam tinjauan teori ilmiah modern perlu dikedepankan sebagai penguatan bagi peserta didik dan menghasilkan lulusan yang marketable.

Peningkatan mutu pendidikan dapat dicapai melalui kolektifitas sistem pendidikan yang melibatkan berbagai aspek seperti kurikulum, kebijakan pendidikan, materi, strategi, pendekatan dan metode pembelajaran, fasilitas, sarana dan prasarana, tenaga pendidik dan kependidikan, proses manajerial yang dilakukan secara professional, proses pembelajaran, aplikasi teknologi informasi dan komunikasi, khususnya dalam proses pembelajaran di kelas, evaluasi yang sesuai serta pengontrolan dan pengendalian mutu pendidikan. Mutu dalam pendidikan untuk menjamin kualitas input, proses, output, dan outcome sekolah sehingga dapat meningkatkan akuntabilitas lembaga pendidikan.

\section{KESIMPULAN}

Peningkatan mutu pendidikan adalah suatu isu sentral yang perlu diperhatikan secara terus menerus. Pertumbuhan ekonomi, perkembangan zaman dengan era teknologi dan informasi serta pergerakan isu sosial dan budaya menjadi beberapa faktor yang menjadi penyebab adanya perbaikan dan peningkatan mutu pendidikan. Tidak hanya untuk mencapai standar pendidikan, namun juga untuk menjawab tantangan zaman, menyikapi tuntutan dunia modern agar lulusan sebuah lembaga pendidikan menjadi lebih siap menghadapi keadaan sebenarnya di masyarakat.

Lembaga pendidikan Islam harus meningkatkan kualitas pendidikannya mulai dari tingkatan Madrasah Diniyah, Raudhatul Athfal (RA), Madrasah Ibtidaiyah (MI), Madrasah Tsanawiyah (MTs), Madrasah Aliyah (MA), sampai pada pendidikan tinggi agama Islam seperti STAIN/IAIN/UIN. Memadukan konsep Edward Deming yaitu Plan, Do, Check, Action (PDCA) dan Trilogi Juran pengelolaan lembaga pendidikan Islam perlu diarahkan pada peningkatan mutu dengan melakukan pembenahan pada aspek perencanaan

mutu/kualitas, pengendalian mutu/kualitas, dan peningkatan mutu/kualitas. Hal tersebut dapat diupayakan dengan meninjau kembali aspek kurikulum pendidikan Islam, materi pelajaran, model dan metode pembelajaran, kualitas pendidik dan tenaga kependidikan, kepemimpinan, serta pemenuhan sarana dan prasarana. Dengan demikian, diharapkan lembaga pendidikan Islam dapat mengalami peningkatan mutu dan mencapai standar pendidikan nasional sebagai upaya menjawan tantangan global. 


\section{Daftar Pustaka}

Deming, W.E., Out of the Crisis, MIT Center for Advanced Engineering Study, Cambridge, MA, 1986.

Ismail, F. "Implementasi Total Quality Management (TQM) di Lembaga Pendidikan", Jurnal Pendidikan Islam IQRA, Vol.2. Nomor 2. (17-34). 2016.

Juran, J. M., Management of Quality, Juran Institute, Inc, Wilton. 1987.

Juran, J., 1986. “The Juran Trilogy”, Quality Progress, vol. 19, no. 8, Aug. 1986, pg. 19. Juran, J.M, Merancang Mutu, Terjemahan Bambang Hartono dari Juran On Quality By

Design, Jakarta: PT. Pustaka Binawan Pressindo,1989.

Kambey, Daniel C., Manajemen Kualitas Total dalam Pendidikan (Terjemahan Buku Total

Quality Management, Edward \& Sallis), Pascasarjana Universitas Negeri Manado, 2004.

Lestari,I Gusti. Penerapan Sistem Manajemen Mutu ISO 9001:2008 di Perusahaan Konstruksi, Ganeç Swara vol. 9 no.1 (121-126). 2015.

Marzuki Mahmud, Manajemen Mutu Perguruan Tinggi, akarta: PT. RajaGrafindo Persada, 2012. Nafis, Ahmadi Syukran. Manajemen Pendidikan Islam, Yogyakarta, LaksBang PressIndo, 2012.

Rosyada, Dede. Madrasah dan Profesionalisme Guru, Depok, Kencana, 2017.

Sallis, E. Total Quality in Education, London, Kogan Page Limited, 2016.

Sani, Ridwan Abdullah. dkk, Penjaminan Mutu Sekolah,(Jakarta: Bumi Aksara, 2015.

Sukmadinata, Nana Syaodih. dkk., Pengendalian Mutu Pendidikan Sekolah Menengah: Konsep,

Prinsip dan Instrumen, (Bandung: Kusuma Karya, 2002.

Susanto, Pendi., Produktivitas Sekolah, Teori dan Praktik di Tingkat Satuan Pendidikan, Bandung:

Alfabeta, 2016.

Tim Redaksi Kamus Besar Bahasa Indonesia Pusat Bahasa, Kamus Besar Bahasa Indonesia, Jakarta: PT. Gramedia Pustaka Utama. 2008.

Abd Aziz, Athoillah Islamy, Saihu. "Existence Of Naht Method In The Development Of Contemporary Arabic Language Taqdir: Jurnal Pendidikan Bahasa Arab dan Kebahasaaraban p - ISSN 2527 - 9807 | e - ISSN 2621 - 115719 Existence Of Naht Method In The Development Of Contemporary Arabic Languag." $T$ aqdir: Jurnal Pendidikan Bahasa Arab dan Kebahasaaraban, 2019, 19-28.

Abd Aziz, Saihu. "Interpretasi Humanistik Kebahasaan: Upaya Kontekstualisasi Kaidah Bahasa Arab." Arabiyatuna 3, no. 2 (2019): 300-314.

Aziz, Abd, Athoillah Islamy, dan Saihu. "Existence of Naht Method in the Development of Contemporary Arabic Language." Taqdir: Jurnal Pendidikan Bahasa Arab dan

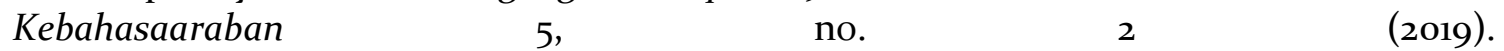
https://doi.org/https://doi.org/https://doi.org/10.19109/taqdir.v5i2.4926.

Saihu, Abd. Aziz, Fatkhul Mubin, Ahmad Zain Sarnoto. "DESIGN OF ISLAMIC EDUCATION BASED ON LOCAL WISDOM (An analysis of Social Learning Theories in Forming Character through NgejotTradition in Bali)." International Journal of Advanced Science and Technology 29, no. 6 (2020): 1278-93.

Saihu. "Implementasi Manajemen Balanced Score Card di Pondok Pesantren Jam'iyyah Islamiyyah Tangerang Selatan.” Mumtaz: 3, no. 1 (2019): 2. https://doi.org/https://doi.org/10.36671/mumtaz.v3i2.45.

___. "Konsep Pembaharuan Pendidikan Islam Menurut Fazlurrahman." Andragogi: Jurnal Pendidikan Islam 2, no. 1 (2020): 85. https://doi.org/org/10.36671/andragogi.viiz.66.

_—_. "Lebaran Sarana Rujuk Nasinal," 2019. http://www.aswajadewata.com/lebaran-saranarujuk-nasional/.

_—_. "Modernisasi Pendidikan Islam." Al Amin: Jurnal Kajian Ilmu dan Budaya Islam 1, no. 1 (2018): 1-33.

- - . "PENDIDIKAN KARAKTER BERBASIS KEARIFAN LOKAL (STUDI DI JEMBRANA

BALI).” Edukasi Islami: Jurnal Pendidikan Islam 8, no. 1 (2019): 69-9o.

___. "Pendidikan Pluralisme Agama: Kajian Tentang Integrasi Agama dan Budaya dalam 
Menyelesaikan Konflik Sosial Kontemporer." Indo-Islamika 9, no. 1 (2019): 67-90.

___. "Pendidikan Sosial Yang Terkandung dalam Surat AT-Taubah Ayat 71-72." Edukasi Islami: Jurnal Pendidikan Islam o9, no. $01 \quad$ (2020): 146. https://doi.org/10.30868/ei.v9io1.703.

___ . "Rintisan Peradaban Profetik Umat Manusia Melalui Peristiwa Turunnya Adam AS Ke-

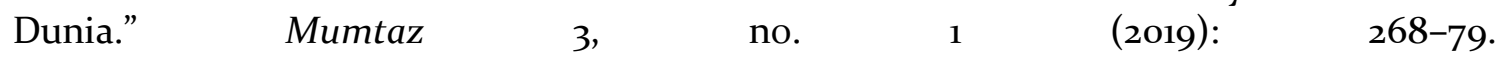
https://doi.org/https://doi.org/10.36671/mumtaz.v3i2.44.

_—_. "Teologi Damai Dari Pesantren," 2019. https://www.aswajadewata.com/teologi-damaidari-pesantren/2019/.

___. "Urgensi 'Urf dalam Tradisi Male dan Relevansinya dalam Dakwah Islam di JembranaBali." Jurnal Bimas Islam 12, no. 1 (2019): 174-201.

——_. "Urgensi Pendidikan Pluralisme," n.d. https://www.aswajadewata.com/urgensipendidikan-pluralisme-agama/2019/.

SAIHU. "KONSEP MANUSIA DAN IMPLEMENTASINYA DALAM PERUMUSAN TUJUAN PENDIDIKAN ISLAM MENURUT MURTADHA MUTHAHHARI." Andragogi 1, no. 2 (2019): 197-217.

- — - "OPERASIONALISASI TEORI PENDIDIKAN BEHAVIORISTIK DALAM TRADISI NGEJOT DI BALI.” Cakrawla: Studi Manajemen Pendidikan Islam Dan Studi Sosial 3, no. 2 (2019): 143-62.

Saihu, Agus Mailana. "Teori pendidikan behavioristik pembentukan karakter masyarakat muslim dalam tradisi Ngejot di Bali." Ta'dibuna 8, no. 2 (2019): 168.

Saihu, Made. Merawat Pluralisme Merawat Indonesia: Potret Pendidikan Pluralisme Agama di Jembrana-Bali. Yogyakarta: DEEPPUBLISH, 2019.

Saihu, dan Cemal Sahin. "The Harmonious Dialectics Between Hindu-Muslim in Bali (A Study in Jembrana Regency)." Religia Jurnal Ilmu-Ilmu Keislaman 80, no. 1 (2020): 56-80.

Saihu, Saihu. "Pendidikan Karakter Berbasis Kearifan Lokal (Studi Di Jembrana Bali)." Edukasi Islami: Jurnal Pendidikan Islam 8, no. or (2019): 69-9o. https://doi.org/10.30868/ei.v8io1.364.

Saihu, dan Taufik. "Perlindungan Hukum Bagi Guru." Al Amin: Jurnal Kajian Ilmu dan Budaya Islam 2, no. 2 (2019): 105.

Wahidin, Adi, Dodi, Fahroji, dan Saihu. “Konsep Dasar Perencanaan,” 2016.

Wekke, Ismail Suardi, Ronaldo Reza, Achmad Zulfikar, Saihu, dan Ismail Suardi Wekke. "International Relation of The Asia Pasific in The Trump." Journal of Enviromental Treatment Techniques 8, no. 1 (2020): 204-6. 
Tugas Jurnal Mata Kuliah Pengelolaan Pendidikan 2020 